
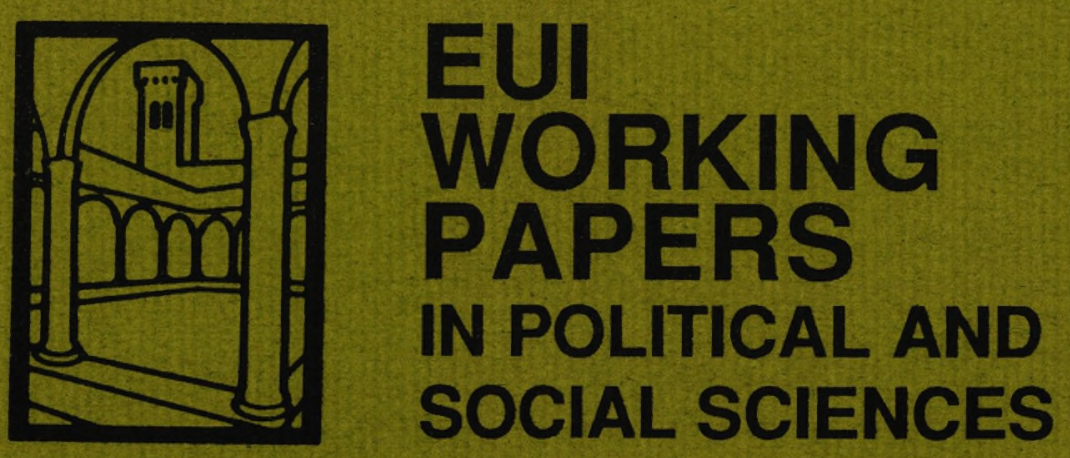

EUI Working Paper SPS No. 90/2

Educational Expansion and Changes in Women's Entry into Marriage and Motherhood

in the Federal Republic of Germany

Hans-Peter Blossfeld and

URSULA JAENICHEN

European University Institute, Florence 
EUI-BIB

As from January 1990 the EUI Working Paper Series is divided into six sub-series, each sub-series will be numbered individually (e.g. EUI Working Paper LAW No 90/1). 


\section{EUROPEAN UNIVERSITY INSTITUTE, FLORENCE}

DEPARTMENT OF POLITICAL AND SOCIAL SCIENCES

EUI Working Paper SPS No. 90/2

Educational Expansion and Changes in Women's Entry into Marriage and Motherhood

in the Federal Republic of Germany

Hans-Peter Blossfeld

and

UASULA JAENICHEN

BADIA FIESOLANA, SAN DOMENICO (FI) 
All rights reserved.

No part of this paper may be reproduced in any form without permission of the authors.

(C) Hans-Peter Blossfeld and Ursula Jaenichen

Printed in Italy in July 1990

European University Institute

Badia Fiesolana

I-50016 San Domenico (FI)

Italy 


\title{
Educational Expansion and Changes in Women's Entry into Marriage and Motherhood in the Federal Republic of Germany
}

\author{
by \\ Hans-Peter Blossfeld \\ and \\ Ursula Jaenichen \\ European University Institute \\ Badia Fiesolana \\ Via dei Roccettini 5 \\ I-50016 San Domenico di Fiesole (FI)
}

Paper prepared for the ESF Workshop on "Applications of the Life Course Approach to Household Dynamics in Contemporary Europe", Ghent, Belgium, 7-9 June 1990. This research was supported by grants from the European University Institute, Florence. We would like to thank Anne Condy and Iain Fraser for their helpful comments on earlier drafts. 


\section{Introduction}

Like all other European countries, the Federal Republic of Germany has undergone unprecedentedly rapid changes in family formation during the last three decades (Caldwell et al. 1988). The trend toward early and universal marriage that was observed for the first two-thirds of the century (Diekmann 1987) has reversed, and age at first marriage is now rising much faster than it fell during the previous period (Höpfinger 1987; Schwarz 1983). Germany is faced with low fertility (Handl 1988a) and an increasing age at entry into first motherhood across birth cohorts (Huinink 1987). Previously rare family types, such as single-parent families, female-headed families and de facto unions, have also become increasingly common (Tölke 1987; Nave-Herz 1988; Meyer/Schulze 1988).

These changes in family formation have not occurred in isolation from changes in the educational system and the labour market (Zimmermann 1985). In Germany, as in all other European countries (see, e.g., Bernhardt 1988, 1989; Sorensen 1990), we observe a re-evaluation of the role of women in society (Sorensen 1990; Huinink 1990), together with increasing female labor force participation (Müller/Willms/Handl 1983; Handl 1988b) and better career opportunities for women at the work place (Blossfeld 1986, 1989). The occupational structure of the labour force is being transformed, and the number of women pursuing higher education has risen (Blossfeld 1987, 1990).

Trends in marriage and fertility have been charted for many societies, but empirical work has relied overwhelmingly on the analysis of cross-sectional data. Although recently there have been several important exceptions, noted below, most of what we know about changes in the family system and their relationship to developments in the educational system and the labour market comes from either census reports or surveys, each referring to distributions at a single point in time. Yet comparative-static analysis cannot easily reveal the causal processes at work (Aalen 1988). We think that it is important to embed macrosociological arguments about the relationship of socioeconomic trends and changes in the family system in a microsociological dynamic framework so that the various dimensions of this process can be disentangled at the level of the life courses of individuals (see also Galler 1989). 
The purpose of this paper is to focus on one specific aspect of these complex relationships. We want to address the question of how the increasing improvement in women's educational attainment across cohorts has influenced the process of family formation in Germany. The paper builds on previous analyses of determinants of the timing of entry into marriage and motherhood (see, e.g., Elder/Rockwell 1976; Hogan 1978; Cherlin 1980; Etzler 1987; Hoem/Rennermalm 1985; Hoem 1985; Marini 1985; Hoem/Hoem 1987a; Diekmann 1987, 1989; Huinink 1987; Bracher 1988; Blossfeld/Huinink 1989; Klein 1989), but goes beyond earlier work in several respects. First, a theoretical framework is presented within which effects of important influences on the timing of entry into marriage and motherhood can be interpreted. In particular, this framework allows the identification of several influences of the improvement of women's educational attainment across cohorts on the process of family formation. Second, a wider range of influences is included in the analysis than has been the case in most earlier research. These include measures of age-dependencies of entry into marriage and motherhood, social class, participation in the educational system, level of education, and cohort membership. And third, the process of family formation is studied on the basis of a continuous succession of birth cohorts born between 1919 and 1968. Thus, cohort comparisons not only reflect the most recent changes in the process of family formation in Germany, but can also be used to examine the long-term impact of educational expansion across a very broad range of birth cohorts. The latter aspect is theoretically interesting because the persistent rise in the proportions of women with better education across birth cohorts occurred during both the fall and rise in the age at marriage and first motherhood.

Our analysis is based on retrospective family and educational histories of individuals from the German Socioeconomic Panel (GSP), one of the most important panel studies ever established in the Federal Republic of Germany (Krupp 1985; Hanefeld 1987). The sample provides data representative of the entire population of West Germany, including foreigners. The GSP was started in 1984, and since then in each year there has been a further wave.

The paper is organized as follows. We first discuss hypotheses about the effects of influences on the timing of entry into marriage and motherhood. We then describe the 
data, the variables and the model we use in order to examine the hypotheses. And finally, we present the findings of the analyses and draw some general conclusions.

\section{Theory and prior research}

Women's timing of entry into marriage and motherhood can be viewed as a function of several time-constant and time-dependent influences. A first, "law-like" time-varying influence is the age dependence of both entry processes. Empirical estimates of the rate of entry into marriage and motherhood reveal a non-monotonic age pattern for different countries, cohorts and social classes (see, e.g., Espenshade 1983; Sorensen/Sorensen 1985; Papastefanou 1987; Diekmann 1989). With increasing age, the rate of entry into marriage and motherhood initially increases until a maximum and then decreases. There are at least three explanations for this bell-shaped relationship (Diekmann 1989).

A first explanation conceives age at marriage as the result of durations in two different states: "not ready for marriage or motherhood" and "ready for marriage or motherhood". Coale and McNeil (1972), for example, argued that the duration until entering the "ready state for marriage" can be considered as normally distributed and that the search time prior to entry into marriage may be thought of as the sum of exponentially distributed durations. A combination of both durations over age then leads to the observed bell-shaped pattern over age.

A second model is based on a search model (Diekmann 1987). It states that the readiness for marriage and motherhood increases linearly with age; and that the degree of this increase varies in the population according to characteristics of the individuals. As a result, a bell-shaped aggregated population rate of entry into marriage and motherhood is observed.

And finally, a third model considers entry into marriage and motherhood as a process of social diffusion. Hernes (1972), for example, holds that there is some kind of social pressure exerted by the married persons (or persons with a child) on the unmarried persons (or persons without a child) within each cohort. She argues that with increasing 
age there is an increasing social pressure inducing imitation and a decreasing chance to find a partner, together leading to the observed bell-shaped age dependence.

What all three of these explanatory models have in common is that they refer to influences on the rate of entry into marriage and motherhood which are conceptually important, but hard - or even impossible - to measure. Another interesting example of such a variable, especially important for the analysis of younger birth cohorts, was recently mentioned by Hoem $(1983,1984)$, who describes distortions caused by nonobservation of periods of cohabitation.

Given the empirical regularity of the bell-shaped age dependence in different countries, cohorts and social classes, it seems reasonable to control for such types of unobserved heterogeneity in our rate models of entry into marriage and motherhood on the basis of measures of a non-monotonic age dependence (Blossfeld/Hamerle/Mayer 1989; Blossfeld/Hamerle 1989; Blossfeld/Huinink 1989).

Apart from unobserved heterogeneity, there are theoretically important influences which can be included in our estimation models at least on the basis of proxy measures. Among these influences we count women's class-specific orientations towards marriage and motherhood. It is well-known from the sociological literature that socioeconomic background has a strong effect on ages at entry into marriage and motherhood (Mayer 1977; Michael/Tuma 1985; Marini 1985; Huinink 1987).

Three different components have been distinguished here (Haller 1981). The first concerns women's class-specific expectations about love and a marriage relationship, which influence the time when women consider themselves as ready for marriage. The second component involves the socioeconomic resources of a woman's family of origin. From this point of view, class differences in educational attainment and career are very important, because it is most common for a woman to leave school before entering into marriage and motherhood. And finally, the third component is the class-structured mateselection process itself. Here, class-specific differences in duration and types of schooling as well as in job careers are important insofar as they structure women's life courses and marriage markets, especially during youth and young adulthood. 
In addition to influences of social class, variations in ages at marriage and motherhood are dependent on the historical background when the woman reaches the ages at which the mate selection process takes place. Caldwell et al. (1988) show for a number of industrialized countries (including the Federal Republic of Germany) that ages at marriage and motherhood fell from the beginning of the century until the $1960 \mathrm{~s}$ and since then have been increasing again (Caldwell et al. 1988). Several explanations have been advanced, especially for the dramatic changes after the $1960 \mathrm{~s}$.

Focusing on the Netherlands, Van de Kaa (1987) considers the recent development as a series of successive events driven largely by social change. He argues that with increasing economic prosperity there has been a transition to "Postmaterialism" which can be characterized by substantial changes in attitudes to marriage, family and sexuality.

Caldwell and Ruzicka (1978) state that the perfection of birth control through contraception and abortion allows young people to separate sexual relations from marriage and leads to an increase in age at marriage in a community where most people still regard marriage as the preliminary to parenthood but not to sexual relations.

Analysing the Federal Republic of Germany, Blossfeld and Huinink (1989) argued that the change in the 1960's could be explained by a lag of norms behind economic development ("cultural lag" hypothesis): until the late 1960s, the opportunity for children to leave their parental home had increased remarkably because of the improvement of economic conditions. But at the same time, the social norm that they had to be married if they wanted to live together with a partner of the opposite sex was still valid. The result was that until the end of the 1960 s, the age at entry into marriage was decreasing because young adults living in consensual unions normally suffered from social disapproval and had great problems, for instance in finding housing, until they were married. This norm was increasingly weakened at the end of the $1960 \mathrm{~s}$ - in part as a consequence of the student revolt. And indeed, the function of students as pioneers of cohabitation is well documented in many early campus studies (Clayton/Voss 1977; Stafford/Backman/Dibona 1977; Newcomb 1979). However, in recent years, cohabitation seems to have been taken up to a similar extent by young 
people from working and middle class families and those with differing levels of education (Bernhardt/Hoem 1985; Kiernen 1989).

Oppenheimer (1988) explains the increasing prevalence of cohabitation among young people by the increasing socioeconomic uncertainties at an earlier age during the last 20 years. "Cohabitation gets young people out of high-cost search activities during a period of social immaturity but without incurring what are, for many, the penalities of either heterosexual isolation or promiscuity, and it often offers many of the benefits of marriage, including the pooling of resources and the economies of scale that living together provide" (Oppenheimer 1988:71).

Caldwell et al. (1988) report that for many people cohabitation is not the same as marriage either in promised permanence or in likely parenthood. Thus, cohabitation seems to be not merely another name for marriage, and the rising age at marriage is more reality than appearance. McDonald (1975) has therefore argued that despite a rise in the incidence of consensual unions most people will ultimately marry; but given the ease with which births can now be planned, marriage has become a less significant life-cycle event than the birth of the first child. "In this view, the present decline in marriage, rather than reflecting more liberal attitudes toward marriage, represents a return to a more conservative ethic in which the timing of marriage is determined by a couple's ability to accumulate sufficient savings to establish themselves in a home before the birth of their first child or, if they plan to delay the first birth after marriage, by their assessment of having reached the 'psychologically proper time' to marry" (Bracher 1988).

Although it will not be possible in this paper to assess empirically all these different hypotheses about the interplay of economic development, changes in values and demographic behavior, we are at least able to control for the long-term historical shifts in ages at entry into marriage and motherhood on the basis of a very detailed set of birth cohort variables. Given these influences, we next become interested in focusing our analysis on the question of how the increasing educational attainment of women affects their ages at entry into marriage and motherhood. 
Economists in particular have been prominent in offering explanations for the relationship between women's growing economic independence (as a result of better education and improved career opportunities) and the rise in delayed marriage and fertility.

According to Becker (1981), the main exponent of the economic theory of the family, unmarried men and women can be viewed as trading partners who decide to marry if each partner has more to gain by marrying than by remaining single. As in all trading relationships, the gains from marriage are based on the fact that each partner has something different to offer (Becker 1981). In our society women traditionally rely on men for provision of food and shelter, as well as protection; and men rely on women for the bearing and rearing of children as well as the maintenance of the home. This means that the socialization process traditionally induces (1) a comparative advantage of women over men in the household because women invest mainily in human capital that raises household efficiency, and (2) a comparative advantage of men over women in the labour market because men invest mainly in capital that raises market efficiency. Hence, according to Becker, it is this sex-specific specialization of labour in our society, and the mutual dependence it produces between the sexes, that provides the major incentive for the partners to marry. On the basis of this argumentation Becker comes to the conclusion that "... the gain from marriage is reduced by a rise in the earnings and labor force participation of women ... because a sexual division of labor becomes less advantageous". (Becker, 1981:248) The result is that women with higher education and better career opportunities increasingly delay or even avoid marriage.

Becker (1981) has not only drawn conclusions from his economic approach to the family with respect to entry into marriage, but also in relation to the decision to have children. According to Becker, the production and rearing of their own children is one of the main purposes of families. Families use market goods and services to achieve this goal, as well as the time of parents. Because of the sex-specific differentiation of labour in the family, it is especially the mother's time that is the major part of the total costs of producing and rearing children. Increases in the value of women's time as a result of increases in investments in education and career opportunities will therefore immediately affect the relative costs of children. Thus Becker argues that "a 
growth in the earning power of women raises ... the relative cost of children and thereby reduces the demand for children ..." (Becker, 1981:245-247)

Given Becker's argumentation, we therefore expect a negative relationship between women's increasing level of education and the rates of entry into marriage and motherhood.

However, apart from the pure quantity of women's human capital investments influencing their time of entry into marriage and motherhood, there may also be a delaying effect coming from women's increasing enrolment in the educational system itself (Hoem 1985; Marini 1985; Etzler 1987; Blossfeld/Huinink 1989). One reason is that several activities, such as acquiring education, tend to be incompatible with adult family role activities (Marini 1985). Another reason is that attending school, university, or vocational training programmes is associated with a high degree of economic dependence on parents (Blossfeld/Nuthmann 1989). Women enrolled in school or vocational training programmes may therefore consider themselves as not being sufficiently "mature" for entry into marriage and motherhood. Thus, finishing education is expected to count as one of the important prerequisites for entering into the adulthood status, and thereby entering into marriage and parenthood.

This is true not only for men, but also for women as over the last four decades their schooling has become more important, and their opportunity costs of dropping out of school before completion have been sharply rising (Oppenheimer, 1988).

Although previous research indicates that both age at first marriage and first birth have effects on the educational enrolment of women too (Hofferth/Moore 1979; Marini 1978, 1984), the dominant direction of influence is from educational enrolment to the timing of entry into marriage and parenthood (Marini 1985).

The separation of the effects of the level of women's educational investments and women's educational enrolment is important for theory and social policy, because the effect of educational enrolment is confined to the period of transition from youth to adulthood and therefore means only a temporary postponement of family events like marriage and the birth of a child. However, the effect of the level of educational in- 
vestments, also initiated during this transition period, will continue throughout much of adult life and therefore reflects a persistent role conflict between women's growing economic independence and their traditional family roles.

\section{Data, methods and variables}

Data

The analysis reported is based on data from the German Socio-economic Panel (GSP). The GSP is a longitudinal project that is part of Sonderforschungsbereich 3 "Microanalytical Foundations of Social Politics" (Mikroanalytische Grundlagen der Gesellschaftspolitik) of the Universities of Frankfurt am Main and Mannheim and has since 1983 been located at the German Institute for Economic Research (Krupp 1985; Hanefeld 1987).

The aim of the GSP is to produce a representative longitudinal data base for the Federal Republic of Germany, to be used in the analysis of a broad range of socioeconomic questions. The first data collection was carried out in 1984, and in each year since there has been a further panel wave. Analyses in this paper use data from panel waves between 1984 and 1988. In the first wave, 12,245 persons from 5,921 households were questioned. There is an extensive methodological literature on the GSP (see, e.g., Hanefeld 1987; Rendtel 1988, 1989).

The GSP data have two main advantages for addressing our research question. First, the GSP is designed to provide longitudinal data for individuals as well as families and households. And second, the data not only provide up-to-date information for the times of the surveys in the years from 1984 until today, but also contain a broad range of retrospective questions which cover a historical period of more than 50 years.

Unfortunately, the GSP data do not permit the reconstruction of consensual unions over this long historical period. This means that we can only study the processes of family formation in terms of entry into marriage and motherhood. However, the increasing prevalence of consensual unions among young people can at least be controlled for in 
our analysis using a detailed set of birth cohort dummy variables as well as a nonmonotonic measure of age dependence. As discussed above, the latter may also be thought of as a measure that controls for unobserved heterogeneity.

For this long historical period, it is not possible to reconstruct women's job careers continuously either. Continuous reconstruction is possible beginning from the year of the first panel. Our analysis will therefore focus only on changes in educational attainment. However, the level of educational investments is also a good predictor of job opportunities (Blossfeld 1989). Hence, the level of educational investments reflects women's career opportunities too.

\section{Methods}

To study the process of family formation, we specify as the dependent variable the instantaneous rate of entry into marriage or motherhood, defined as

$$
\begin{aligned}
r(t)= & \lim P(t<=T<t+d t / T>=t) / d t \\
& d t \rightarrow 0 \\
& d t>0
\end{aligned}
$$

where $\mathrm{P}($.$) is the instantaneous probability of entering into marriage or motherhood in$ the interval $(\mathrm{t}, \mathrm{t}+\mathrm{dt})$, respectively, provided that such an entry has not occurred before the beginning of this interval (see, e.g., Blossfeld/Hamerle/Mayer 1989, Tuma/Hannan 1984).

Using an exponential model, our goal is to specify the rates of entry into marriage and motherhood as a function of time-constant $\left(\mathrm{X}_{1}\right)$ and time-dependent covariates $\left(\mathrm{X}_{2}(\mathrm{t})\right)$ (Blossfeld/Huinink 1989):

$r\left(t / X_{1}, X_{2}(t)\right)=\exp \left(\beta_{1} X_{1}+B_{2} X_{2}(t)\right)$

Observation begins at age 16 and ends with the event of first marriage or the birth of the first child, or, for right censored cases, with the date of the interview or age 46 , whichever is the earlier. 
To introduce the time-dependent measures into the rate equation, we use the method of episode-splitting (cf., Blossfeld/ Hamerle/Mayer 1989). A separate data record was created for maximal half-year interval spans. For each of these records four different pieces of information were provided: (i) time at the beginning and end of the interval to which the record pertains; (ii) the values of the time-dependent covariates at the beginning of these intervals; (iii) whether the interval ended with an event or not; and (iv) the values of the other covariates relevant for the analysis.

\section{Variables}

The independent variables include measures of age-dependence, social class, cohort and education. We used a combination of two variables to control for the well-known nonmonotonic age dependence of the marriage rate and the rate of first birth (Coale 1971; Bloom 1982). This approach assumes that women are at risk of entering first marriage and of having a first child between the ages 16 and 46 (whereby $i$ is an index for the i-th interval):

$\log \left(D_{i}\right)=: \log ($ current age -16$)$

$\log \left(R_{i}\right)=: \log (46$ - current age $)$.

Including these variables in the exponential model as time-dependent covariates,

$\exp \left(\log \left(\mathrm{D}_{\mathrm{i}}\right)^{*} \mathrm{~B}^{\prime}+\log \left(\mathrm{R}_{\mathrm{i}}\right)^{*} \mathrm{~B}^{\prime \prime}\right)=\mathrm{D}_{\mathrm{i}}^{\mathrm{B}^{\prime}} * \mathrm{R}_{\mathrm{i}}^{\mathrm{B}^{\prime \prime}}$

models the typical bell-shaped curve of the rates of entry into first marriage and first motherhood. This curve is symmetric around the age 31 for $\beta^{\prime}=\beta^{\prime \prime}$, left-skewed (this means marriages or births are clustered more to the left of the mean with most of the extreme values to the right) for $B^{\prime}<B^{\prime}$, and right-skewed (this means marriages or births are clustered to the right of the mean) for $B^{\prime}>B^{\prime \prime}$.

In order to model women's accumulation of general and vocational qualifications in the general school system, the vocational training system and the university system of the Federal Republic of Germany, we use the average number of years required to obtain 
them (Blossfeld 1985): lower school qualification without vocational training = 9 years; lower secondary school qualification with vocational training $=11$ years; intermediate school qualification without vocational training $=10$ years; intermediate school qualification with vocational training $=12$ years; upper secondary school qualification (Abitur) $=13$ years; professional college qualification $=17$ years and university degree $=19$ years. To model changes in the accumulation of these qualifications over the life course, we have for each woman updated the level of education at the age when she is supposed to obtain each higher level in this hierarchy. For example, for a woman who attains a lower school qualification at age 14, reaches the intermediate school qualification at age 16, leaves school with an Abitur at age 19, and finally finishes her studies at the university at age 25 , we would obtain a picture of changing levels of education over the life course as shown in the upper panel of figure 1.

Insert figure 1 about here

However, as indicated above, there may also be other effects of education on the timing of family formation. Enrolment in the educational system takes time and affects a woman's ability to marry and to have a first child. In order to include this influence in our model, we generated a time-dependent dummy variable, indicating whether or not a woman is attending the educational system at a specific age (cf., the lower panel of figure 1).

As time-constant background variables we include father's social class. On the basis of the GSP we can only use a very constrained set of class categories: farmers, unskilled and skilled manual workers, unskilled and skilled administrative and service workers, professionals, and selfemployed. The unskilled manual worker class is used here as the reference category.

Our analysis studies the process of entry into marriage and motherhood during a historical period of about 50 years. The oldest cohort studied were born between 1919 and 1923 and entered into marriage and motherhood during the period stretching from the late 1930 s to the late 1940 s. Thus, they began family formation during the Third 
Reich and the turbulence generated by the Second World War. The youngest cohort analysed were born between 1964 and 1968 and started to enter marriage and motherhood during the $1980 \mathrm{~s}$. Thus, they began family formation during a period of high educational expansion and economic uncertainty. To control for cohort effects generated by historical events, changes in values and economic development, we used a set of dummy variables each representing five-year birth groups from 1919-23, 1924-28, ,.., to 1964-68 $($ reference group $=$ cohort 1919-23) .

\section{Results}

\section{Effects of educational expansion}

As discussed above, important changes in the timing of entry into marriage and fertility are frequently attributed to changes in women's educational attainments. Accordingly, we start our empirical analysis by asking the question: What are the effects of the educational expansion on the levels of women's educational attainment in successive cohorts in Germany?

Insert table 1 about here

Distributions of educational attainment for women from successive cohorts are shown in table 1 . If we compare the educational attainments of the cohort 1919-23 with those of the 1954-58 and 1959-63 cohorts, then the improvement in educational chances for women is clear. Women have profited from the educational expansion at all levels of higher qualification. For the 1919-23 birth cohort, the proportion of women with lower secondary school qualification without vocational training was about five times as large $(51.4 \%)$ as it was for the $1959-63$ cohort $(10.4 \%)^{1}$. Conversely, compared to the 1954 58 cohort, women of $1919-23$ cohort were less likely to have intermediate school with

1 The 1964-68 cohort is not comparable because in 1988, the year of the last available panel wave, many women were still enrolled in school. 
vocational training ( $26.2 \%$ vs. $12.9 \%$ ), Abitur with vocational training ( $8.2 \%$ vs. $1.7 \%$ ), professional college qualification $(2.6 \%$ vs. $0.7 \%)$, or a university degree $(2.1 \%$ vs. $10.0 \%)^{2}$

In general, educational expansion led in a first phase to a decrease in women without vocational training and to a strong increase in women with vocational training (from the 1919-23 cohort to the 1949-53 cohort) and then, in a second phase, to a decrease in women with vocational training and a steep increase in women with higher formal educational qualifications, like Abitur or a university degree.

The central point of this description for our argumentation is that there has been a monotonic, long-term trend across successive birth cohorts: not only have women's average levels of educational attainment steadily risen from birth cohort to birth cohort,, but women's enrolment in the educational system over the life course was likewise increasingly extended.

\section{Changes in women's ages at entry into marriage and motherhood}

Next, we consider changes in the process of women's entry into marriage and motherhood across successive birth cohorts in Germany. Tables 2 and 3 show for each birth cohort and specific ages the percentages of women who have not yet entered first marriage or first birth. These percentages are based on estimations of survivor functions for each cohort for the events of entry into marriage and first birth (see, e.g., Blossfeld/Hamerle/Mayer 1989).

Insert tables 2 and 3 about here

As shown in table 2, ages at first marriage fell sharply from the 1919-23 cohort to the 1944-48 cohort, and have since been rising again until the youngest birth cohort. The

2 The 1959-63 cohort is not comparable, because in 1988, the year of the last available panel wave, many were still enrolled in professional colleges and universities. 
greatest movements occurred amongst women aged 20-24, where the proportion unmarried dropped from $46 \%$ to $15 \%$ and then increased to $40 \%$ again. The result is that as far as the youngest cohorts, 1964-68 and 1959-63, can be followed, they have more or less the same age pattern at entry into marriage as we find for the oldest cohorts, $1924-28$ and $1919-23$.

Looking at ages at entry into first birth in table 3, we observe a similar trend. Again, it is the 1944-48 cohort which entered motherhood at the youngest ages. For this cohort not only marriages but entries into motherhood too were highly concentrated. And again, we find more or less the same time pattern of entry into motherhood for the youngest cohorts, 1964-68 and 1959-63, and the oldest cojorts, 1924-28 and 191923, at least as far as the youngest cohorts can be followed.

Several points are important for our discussion. At least in Germany, the delay in entry into marriage and motherhood seems to be less dramatic than has been shown for other countries, such as the Scandinavian ones, especially Sweden (Hoem/Hoem 1987). In Germany, up to now, more or less the same entrance pattern of ages into marriage and motherhood is observed as was already established 50 years ago. However, it is clear that in Germany too the earlier movement toward younger and universal marriage and motherhood had come to a halt at the end of the 1960 s and the beginning of the 1970 s. But this reversal of the timing of marriage and motherhood is not in synchrony with the trend in women's educational attainment across cohorts. At this point in our discussion, it is therefore highly questionable whether changes in marriage and motherhood can be attributed mainly to women's growing economic independence (as a result of better education and improved career opportunities), as for example Becker (1981) has argued. To assess Becker's hypothesis, however, a more detailed analysis of the processes of entry into marriage and motherhood is necessary.

\section{Effects of education on the rate of entry into first marriage}

We begin this more detailed analysis with the question of how the improvement of educational attainment of women across cohorts has affected their entry into first marriage. We find it most useful to control in a step-wise manner for other important influences before we focus on the variables of interest here, namely the dynamic 
measure of educational level and the dynamic measure of enrolment in the educational system.

All coefficients in the models are metric coefficients, but we will not compare the relative magnitude of the effects of different variables within models because they depend on the scale by which variables are measured. Instead, we rely on the significance level of variables to decide whether there is an important influence of a variable or not. In evaluating a model's performance we also use a likelihood ratio test, comparing the model to a baseline. The baseline for all models is model 1 , the constant-rate model. This test gives chi-square values which are reported in tables 4 and 5 .

Insert table 4 about here

Model 2 in table 4 includes in a first step two independent variables, Log (current age - 16) and $\log (46$ - current age). As discussed earlier, both measures may serve also as a control for unobserved heterogeneity such as psychological readiness for marriage, distortions caused by nonobservation of periods of cohabitation etc. Both coefficients are significant at the 0.05 level, which means that there is indeed a nonmonotonic pattern of the observed marriage rate in the data. Because the B-coefficient of $\log (46-$ current age) is greater than the B-coefficient of $\log$ (current age - 16), we have a left-skewed "bell-shaped" curve for the risk. This type of structure of the age dependence of the marriage rate remains the same across all models.

Mode1 3 in table 1 introduces, in a second step, several dummy variables for father's social class. As noted above, father's social class is considered in the sociological literature to be important for family formation. The estimates show that women from unskilled manual worker families (the reference group) marry much earlier than women from all other social classes. There is a continuously increasing average age at entry into marriage for women coming from skilled manual worker families, unskilled and skilled administrative and service worker families, and families of professionals. The mean ages of entry into marriage for women from farmer families and selfemployed 
families are located in between the skilled administrative and service worker families and the families of professionals.

Of course, these differences in the age at entry into marriage are a reflection of differences in class-specific resources determining life chances of children. These resources comprise not only income positions, properties, consumption styles and economic strategies of the families of origin, but also their social orientations, values, and beliefs, which influence educational and career decisions of children (cf., e.g. Blossfeld 1988; Huinink 1987). In later steps of this paper we shall see to what extent these effects of social origin have been transformed over the life course into prolonged schooling, and what effect of social class on family formation remains once these influences are controlled for.

Model 4 in table 4 incorporates changes in the historical background, measured on the basis of a detailed set of cohort dummy variables. The reference category is the oldest birth cohort, 1919-23. As expected on the basis of the results in tables 2 and 3, we observe that there is a non-monotonic relationship across cohorts. The strongest positive cohort effect is found for the 1944-48 cohort. Although most of the younger and older cohorts have more or less the same coefficients, there is a significant negative effect for the youngest cohort, 1964-68. In the next step of our analysis, we shall see how much of this delaying effect can be attributed to the expansion of women's educational attainment.

After having controlled for age dependence, social class and cohort membership, we can now try to answer the question of how important the improvement in educational opportunities has been for women's timing of marriage across cohorts.

As discussed above, the theoretical importance of education may be viewed from two different perspectives. First, from the perspective of the "new home economists", the accumulation of human capital as reflected by an increasing level of education raises women's labour-market attachment and thereby leads to greater marriage delays (Mincer 1974; Becker 1981). And secondly, from a sociological point of view there exist normative expectations in the society that young people who attend school are "not mature" for entering marriage. Finishing education should therefore count as one of the 
important events in becoming ready for marriage (Marini 1985; Oppenheimer 1988; Blossfeld/Nuthmann 1989). We have constructed dynamic, time-dependent measures for both aspects of the effects of education and included them in model 5 in table 1 . This model shows that enrolment in school, vocational training or university indeed has a strong and significant negative effect on the rate of entry into marriage. However, and very interestingly, the effect of the level of education is not significant. Women's timing of marriage is therefore independent of the amount of human capital investment. In assessing the consequences of educational expansion for family formation, we may therefore conclude that higher-educated women postpone marriage because they postpone their transition from youth to adulthood. The conflict between women's increasing educational attainment and marriage is therefore confined to the period of transition from youth to adulthood and does not seem to continue throughout much of adult life. Hence, it seems not to be justified to attribute the decline in marriage in our society to the improvement in women's educational attainment.

Once we have controlled for women's educational histories, most of the effects of father's social class prove to be still significant. In other words, besides class differences in educational enrolment, there seem to be important class-specific variations in expectations about marriage which influence the timing at which women regard themselves as ready for marriage.

It is also important for our discussion to note that after controlling for women's educational attainment, we observe a much stronger non-monotonic pattern of cohort effects. This means that apart from the postponement of marriage because of women's increasing enrolment there are other - and probably more important - sources of cohortspecific influences which lead to a change in the ages of entry into marriage for younger birth cohorts.

In order to take changes in the meaning and importance of education across cohorts of women into account too, we included interaction effects of cohort membership with level of education and enrolment in the educational system. The interaction effects were not significant, and they are therefore not reported in table 1 . 
Finally, we also considered the relationship between marriage and parenthood. We introduced a time-dependent covariate for those who got pregnant (model 6 in table 4). Although this variable proves to be the strongest predictor for entry into marriage among those that have been included, the main pattern of the effects of all other variables in the rate equation and their substantive interpretation stays the same.

\section{Effects of education on the rate of entry into first motherhood}

Let us now consider changes in the age at which women have their first child (table 5). We observe very similar effects for age dependence, social class and cohort membership in the first four models of table 5 as we did in table 4 . Because their interpretation is analogous, we do not repeat the substantive explanation. However, it is important to note that, compared to the cohort effects on age at marriage, the nonmonotonic pattern of cohort effects of age at first child is less pronounced and the rise in average ages of younger cohorts is steeper. This means that across cohorts there is an increasing gap between ages at entry into marriage and entry into motherhood.

Insert Table 5 about here

After having controlled in table 5 for these important influences, in model 6 we include women's continuously changing level of education and a time-dependent indicator for their enrolment in the educational system, so as to explain the rate of entry into motherhood. Again, attending the educational system negatively affects women's propensity to have a first child. There exist normative expectations in the society that young women who are enrolled in school are "not ready" for having a baby. Finishing education, as one of the important steps for entering adulthood status, thus leads to a steep rise in the rate of entry into parenthood (cf., e.g., Blossfeld/Nuthmann, 1989).

In contrast to the marriage model, however, the level of education now has a significant negative influence on the timing of the first birth. The accumulation of human capital investments leads to a conflict with societal expectations, connected with a 
woman's role as a mother. This conflict is not limited to the period of transition from youth to adulthood, but will continue throughout much of adult life and therefore reflects a persistent conflict between women's growing economic independence and their traditional roles as mothers. Women are still responsible in our society for rearing children. And women are still disadvantaged in their careers when they have to interrupt them because of the birth of a child (Ott/Rolf 1987). Women who have accumulated a high stock of human capital therefore try to postpone or even to avoid the birth of the first child.

Again, we have considered how changes in the meaning and importance of education across cohorts of women have affected the rate of entry into motherhood. But again these interaction effects of cohort with level of education and enrolment in the educational system were not significant. We therefore do not report these effects in table 5 .

Finally, in model 6 in table 5 we introduced a time-dependent dummy variable that changes its value at marriage and thus shows whether or not a woman was married before the birth of the first child. This variable increases the rate of entry into motherhood remarkably. Introducing this variable, one can observe that the negative effect of "In training" becomes weaker, but does not affect "Level of education". Pari of the influence of "In training" is therefore mediated by the marriage process.

In introducing marriage as a time-dependent variable, the effects for the cohorts born between 1949 and 1964 become increasingly negative, indicating an increasing time span between age at entry into marriage and age at entry into first birth. This reflects the fact that these cohorts had better access to contraceptive methods, especially oral contraceptives, which allowed them to control fertility better and to postpone the birth of the first child.

\section{Summary and conclusions}

The purpose of this paper has been to assess empirically the question of whether women's growing economic independence, resulting from better education, is one of the 
major factors in the rise in delayed marriage and motherhood in the Federal Republic of Germany. Using retrospective data from the Socioeconomic Panel we described women's long-term educational attainment and women's ages at entry into marriage and motherhood across cohorts. Then we modelled women's educational investments and their enrolment in the educational system as a continuously changing process over the life course, and estimated their effects on the rate of entry into first marriage and first motherhood. There are several results of substantive importance:

First, in describing the effects of educational expansion on the levels of women's educational attainment in successive birth cohorts, we found a monotonic, long-term trend: not only have women's average levels of educational attainment steadily risen from birth cohort to birth cohort, but their enrolment in the educational system over the life course was increasingly extended too.

Second, in charting changes in the process of women's entry into marriage and motherhood across cohorts, we have seen that the long-term trend in ages at entry into marriage and motherhood is not in synchrony with the long-term trend in women's educational attainment. Ages at first marriage and first birth fell sharply from the 191923 cohort until the 1944-48 cohort and have since been rising again until the youngest birth cohort. On the basis of this observation, it seemed highly unlikely that women's growing economic independence (as a result of better education and improved career opportunities) can be a major factor for changes in ages at marriage and motherhood.

Third, the recent rise in ages at entry into marriage in Germany seems to be less dramatic than has been suggested in the scientific and social-policy debates. Up tc now, more or less the same pattern for ages of entry into marriage is observed as was already established 50 years ago. It is only relative to the $1944-48$ cohort that the recent marriage patterns appear so dramatic. However, as Kiernan (1989) points out, this generation of women became brides at the earliest average age ever recorded since civil registration started. It is therefore important in analysing the effects of women's improvement in educational attainment on the timing of marriage and motherhood to cover a very long period rather than a period that starts after the Second World War. 
The Federal Republic of Germany may, however, simply be a laggard in these developments, because Germany is behind the development in other countries, especially Scandinavian countries like Denmark or Sweden (Hoem/Hoem 1987b; Hoem 1988). This lag seems to be closely connected with the prevalence of cohabitation in these countries. In the Federal Republic of Germany, the prevalence of cohabitaion amongst young people is less than in Denmark and Sweden. At the beginning of the 1980s, in Denmark and Sweden over 40 per cent were cohabitating at ages of 20-24, whilst in the FRG the comparable figure is only 12 per cent (Kiernan 1989).

Fourth, although our understanding of the causes of this change from marriage-and-birth boom to marriage-and-birth bust is imperfect, on the basis of the present analysis we can at least say that women's educational attainment plays only a minor role.

In analysing the processs of first marriage, we showed that the delaying effect of educational expansion on the timing of first marriage is limited to the phase of transition from youth to adulthood only. After controlling for women's educational attainment, we observe an even stronger non-monotonic pattern of cohort effects on entry into marriage. This means that we must look for other explanations for increasing ages at marriage. However, to base such an explanation solely on an argument of normative or ideological change seems rather unsatisfactory, since this change is normally unmeasured and can therefore be made to explain anything (Bracher 1989).

This does not mean that normative change can be ignored. However, we should first look for other structural explanations. Oppenheimer (1988), for example, has put forward an explanation of the rising age at marriage that is based on the deterioration of young men's labour market position. Or Hobcraft and Joshi (1989) have argued that cohabitation is strongly related to the nature of the housing market. More fluid housing markets are associated with children leaving home much earlier.

Finally, the analysis of the effect of educational attainments on the rate of entry into motherhood has provided an interesting result. Again, prolonged participation in the educational system leads to a delay in the transition to adulthood by women, and therefore to a delay in having a first child. A confirmation of the hypothesis of the "new home economics" may be seen in the negative effect of the level of education on the rate of entry into motherhood. In our society there still exists an economically 
based conflict between women's accumulation of human capital and societal expectations connected with their role as mothers. The economic approach to the family is therefore right insofar as women are still primarily responsible for the rearing of children. Thus, women with increasing human capital are increasingly faced with a conflict, and try to postpone or even to avoid the birth of a first child. With further educational expansion, solutions to this conflict will turn out to be increasingly important for society.

There is, however an interesting result from a similar study by Blossfeld and Huinink (1990) which shows that the impact of educational expansion on the increase in age at first birth has its limits. When gains from women's jobs and careers were controlled for in a time-dependent way, then the impact of the level of education on the rate of entry into motherhood became positive. This means that attaining successively higher levels of qualification did not then decrease, but instead increase, the rate of having a first child. The reason is that attainment of increasing levels of education takes time and is connected with increasing age of women. More highly qualified women who leave the educational system later come increasingly under pressure because of increasing medical problems with late first births, as well as societal age-norms (Menken 1985). 


\section{References}

Aalen, O.D. (1988): "Dynamic modelling and causality," in: Scand. Actuarial Journal, $12,177-190$.

Becker, G.S. (1981): A treatise on the family. Cambridge.

Bernhardt, E.M. (1988): Changing family ties, women's position and low fertility, Stockholm Research Reports in Demography, No. 46, University of Stockholm.

Bernhardt, E.M. (1989): Fertility and employment, Stockholm Research Reports in Demography, No. 55, University of Stockholm.

Bernhardt, E.M. and B. Hoem (1985): "Cohabitation and social background: trends observed for swedish women born between 1936 and 1960," in: European Journal of Population, 1, 375-395.

Bloom, D.E (1982): "What's happening to the age at first birth in the United States? study of recent cohorts," in: Demography, 19, 351-370.

Blossfeld, H.-P. (1985): Bildungsexpansion und Berufschancen. Frankfurt a. M./New York.

Blossfeld, H.-P. (1986): "Career opportunities in the Federal Republic of Germany: dynamic approach to the study of life-course, cohort, and period effects," in: Europear Sociological Review, 2, 208-225.

Blossfeld, H.-P. (1987): "Labor market entry and the sexual segregation of careers in the Federal Republic of Germany," in: American Journal of Sociology, 93, 89-118.

Blossfeld, H.-P. (1989): Kohortendifferenzierung und Karriereprozeß. Frankfurt M./New York.

Blossfeld, H.-P. (1990): "Changes in educational careers in the Federal Republic of Germany," in: Sociology of Education, forthcoming.

Blossfeld, H.-P. and A. Hamerle (1989): "Unobserved heterogeneity in hazard rate models: a test and an illustration from a study of career mobility," in: Quality and Quantity, 23, 129-141.

Blossfeld, H.-P., A. Hamerle and K.U. Mayer (1989): Event history analysis. Hillsdale (NJ).

Blossfeld, H.-P. and J. Huinink (1989): "Die Verbesserung der Bildungs- und Berufschancen von Frauen und ihr Einfluß auf den Prozess der Familienbildung," in: Zeitschrift für Bevölkerungswissenschaft, 15, 383-404.

Blossfeld, H.-P. and J. Huinink: "Effects of educational expansion and the improvement of career opportunities of German women on the process of family formation," in: American Journal of Sociology, forthcoming. 
Blossfeld, H.-P., Nuthmann, R. (1989): "Strukturelle Veränderungen der Jugendphase als Kohortenprozeß," in: Zeitschrift für Pädagogik, 35, 845-867.

Bracher, M. (1988): A Reconsideration of First Marriage - Trends in Australia. Working Paper No. 7 of the Australian Family Project. Research School of Social Sciences. The Australian National University. GPO Box 4. Canberra. ACT 2601.

Caldwell, J.C., P. Caldwell, M.D. Bracher and G. Santow (1988): The contemporary marriage and fertility revolutions in the West. Working Paper No. 3 of the Australian Family Project. Research School of Social Sciences. The Australian National University. GPO Box 4. Canberra. ACT 2601.

Caldwell, J.C. and L.T. Ruzicka (1978): "The Australian fertility transition: an analysis," in: Population and Development Review, 4, 94-96.

Cherlin, A. (1980): "Postponing marriage: the influence of young women's work expectations," in: Journal of Marriage and the Family, 42, 355-365.

Clayton, S. and H.L. Voss (1977): "Shacking up: Cohabitation in the 1970's," in: Journal of Marriage and the Family, 39, 273-283.

Coale, A.J. (1971): "Age Patterns of Marriage," in: Population Studies, 25,193-214.

Coale, A.J. and D.R. McNeil (1972): "The distribution by age of the frequency of first marriage in a female cohort," in: Journal of the American Statistical Association, 67, 743-749.

Diekmann, A. (1987): Determinanten des Heiratsalters und Scheidungsrisiko. Habilitationsschrift. Institute for Sociology, University of Munich.

Diekmann, A. (1989): "Diffusion and survival models for the process of entry into marriage," in: Journal of Mathematical Sociology, 14, 31-44.

Elder, G.H., Jr. and R. C. Rockwell (1976): "Marital timing in women's life patterns," Journal of Family History, 1, 34-53.

Espenshade, Th. J. (1983): "Marriage, divorce, and remarriage from retrospective data: a multiregional approach," in: Environment and Planning, A, 15, 1633-1652.

Etzler, C. (1987): Education, cohabitation and the first child: some empirical findings from Sweden, Stockholm Research Reports in Demography, No. 34, University of Stockholm.

Galler, H.P. (1989): "Dynamische Mikroanalyse als demographische Forschungsstrategie," in: Wagner, G., N. Ott and H.-J. Hoffmann-Nowotny (eds.): Familienbildung und Erwerbstätigkeit im demographischen Wandel, Berlin et al., 61-75.

Haller, M. (1981): "Marriage, women, and social stratification: a theoretical critique," in: American Journal of Sociology, 86, 766-795. 
Handl, J. (1988): "Der langfristige Geburtenrückgang in Deutschland - Heiratskohorten 1920 - 1960," in: Zeitschrift für Bevölkerungswissenschaft, 14, 295-322.

Handl, J. (1989): Berufschancen und Heiratsmuster. Frankfurt a. M./New York.

Hanefeld, U. (1987): Das Sozio-ökonomische Panel. Grundlagen und Konzeption, Frankfurt a.M./New York.

Hernes, G. (1972): "The process of entry into first marriage," in: American Sociological Review, 37, 173-182.

Hobcraft, J. and H. Joshi (1989): "Population matters," in: Joshi, H. (ed.): The changing population of Britain, Oxford, pp. 1-11.

Hoem, B. (1988): Early phases of family formation in contemporary Sweden, Stockholm Research Reports in Demography, No. 47, University of Stockholm.

Hoem, B. and J.M. Hoem (1987a): Patterns of deferment of first birth in moderit Sweden, Stockholm Research Reports in Demography, No. 42, University of Stockholm.

Hoem, B. and J.M. Hoem (1987b): The Sedish family: aspects of contemporary developments, Stockholm Research Reports in Demography, No. 43, University of Stockholm.

Hoem, J.M. (1983): "Distortions caused by nonobservation of periods of cohabitation before the latest," in: Demography, 20, S. 491-506.

Hoem, J. (1984): Marriages connected with first births among cohabiting women in thes Danish fertility survey of 1975, Stockholm Research Reports in Demography, No. 19, University of Stockholm.

Hoem, J.M. (1985): The impact of education on modern union intitiation, Stockholm Research Reports in Demography, No. 27, University of Stockholm.

Hoem, J. and B. Rennermalm (1985) "Modern family initiation in Sweden: experience of women born between 1936 and 1960," in: European Journal of Population, 1, 81112.

Hofferth, S.L. and K.A. Moore (1979): "Early childbearing and later economic wellbeing," in: American Sociological Review, 44, 784-815.

Hogan, D.P. (1978): "The effects of demographic factors, family background, and early job achievement on age at marriage,", in: Demography, 15, 139-160.

Höpfinger, F. (1987): Wandel der Familienbildung in Westeuropa, Frankfurt a. M./New York.

Huinink, J. (1987): "Soziale Herkunft, Bildung und das Alter bei der Geburt des ersten Kindes," in: Zeitschrift für Soziologie, 16, 367-384. 
Huinink, J. (1990): "Familienbildung und Geburtenentwicklung," in: Mayer, K.U. (Hg.): Lebensverläufe und gesellschaftlicher Wandel - Zwischen Sozialdemographie und Biographie, Sonderband der Kölner Zeitschrift für Soziologie und Sozialpsychologie, forthcoming.

Kiernan, K.E. (1989): "The family: formation and fission," in: Joshi, H. (ed.): The changing population of Britain, Oxford, pp. 27-41.

Klein, T. (1989): "Bildungsexpansion und Geburtenrückgang," in: Kölner Zeitschrift für Soziologie und Sozialpsychologie, 41, 483-503.

Krupp, H.-J. (1985): Das Sozio-ökonomische Panel. Bericht über die Forschungstätigkeit 1983-1985. Antrag auf Förderung der Forschungsphase 1986-1988, Frankfurt a.M./Berlin.

Marini, M.M. (1978): "The transition to adulthood: sex differences in educational attainment and age at marriage," in: American Sociological Review, 43, 483-507.

Marini, M.M. (1984): "Women's educational attainment and the timing of entry into parenthood," in: American Sociological Review, 49, 491-511.

Marini, M.M. (1985): "Determinants of the timing of adult role entry," in: Social Science Research, 14, 309-350.

Mayer, K.U. (1977): Fluktuation und Umschichtung. Habilitationsschrift. University of Mannheim.

McDonald, P.F. (1975): Marriage in Australia, 1860-1971, Australian Family Formation Monograph No. 2, Canberra, The Australian National University.

Menken, J. (1985): "Age and fertility: how late can you wait?", in: Demography, 22, 469-483.

Meyer, S. and E. Schulze (1989): Balancen des Glücks, München.

Michael, R.T. and N.B. Tuma (1985): "Entry into marriage and parenthood by young men and women: the influence of family background," in: Demography, 22, 515-543.

Mincer, J. (1974): Schooling, experience, and earnings. New York.

Müller, W., A. Willms and J. Handl (1983): Strukturwandel der Frauenarbeit 18801980. Frankfurt a.M./New York.

Nave-Herz, R. (Hg.) (1988): Wandel und Kontinuität der Familie in der Bundesrepublik Deutschland, Stuttgart.

Newcomb, P.R. (1979): "Cohabitation in America: an assessment of consequences," in: Journal of Marriage and the Family, 41, 597-603.

Oppenheimer, V. K. (1988): "A theory of marriage timing," American Journal of Sociology, 94, 563-591. 
Ott, N. and G. Rolf (1987): Zur Entwicklung von Frauenerwerbstätigkeit und Geburtenhäufigkeit. Arbeitspapier Nr. 244 des Sfb 3 der DFG "Mikroanalytische Grundlagen der Gesellschaftspolitik". Frankfurt a. M.

Papastefanou, G. (1987): Familienbildung und Lebensverlauf. Eine empirische Analyse sozialstruktureller Bedingungen der Familiengründung bei den Kohorten 1929-31, 193941 und 1949-51. Dissertation, Berlin.

Rendtel, U. (1988): Repräsentativität und Hochrechnung der Datenbasis," in: Krupp, H.J. and J. Schupp (eds.): Lebenslagen im Wandel - Daten 1987, Frankfurt a.M./New York, 289-308.

Rendtel, U. (1989): "Über den Einfluß der Panelselektivität auf Längsschnittanalysen," in: Vierteljahreshefte zur Wirtschaftsforschung, Heft 1, 45-61.

Rindfuss, R.R., John, C.St. (1983)

Social Determinants of Age at First Birth. Journal of Marriage and the Family, S. 553 565 .

Santow, G. (1989): Work and Family in the Lives of Australian Women. Pape Prepared for the Symposium "Life Histories and Generations", June 22-23. Netherlands Institute for Advanced Study in the Humanities and Social Sciences. Wassenaar. The Netherlands.

Schwarz, K. (1983): "Die Alleinlebenden," in: Zeitschrift für Bevölkerungswissenschaft, 9, 241-257.

Sorensen, A.B. and A. Sorensen (1985): "An event history analysis of the process of entry into first marriage," in: Current Perspectives on Aging and Life Cycle, 2, 53-71.

Sorensen, A. (1990): "Gender and the life course," in: Mayer, K.U. (Hg.) Lebensverläufe und gesellschaftlicher Wandel - Zwischen Sozialdemographie und Biographie, Sonderband der Kölner Zeitschrift für Soziologie und Sozialpsychologie, forthcoming.

Stafford, R., E. Backman and P. Dibona (1977): "The division of labor among cohabiting and married couples," in: Journal of Marriage and the Family, 39, 43-57.

Tölke, A. (1987): Lebensverläufe von Frauen. Familiäre Ereignisse, Ausbildungs- und Erwerbsverhalten im Kontext des individuellen Lebenslaufs und der gesellschaftlichen Entwicklung. Dissertation, Frankfurt a.M.

Tuma, N.B. and M.T. Hannan (1984): Social Dynamics. Models and Methods. New York.

Van de Kaa, D.J. (1987): "Europe's second demographic transition," in: Population Bulletin, 42.

Zimmermann, K.F. (1985): Familienökonomie. Theoretische Untersuchungen zur Frauenerwerbstätigkeit und Geburtenentwicklung. Berlin/Heidelberg 
twre 1: Educational career over the life course

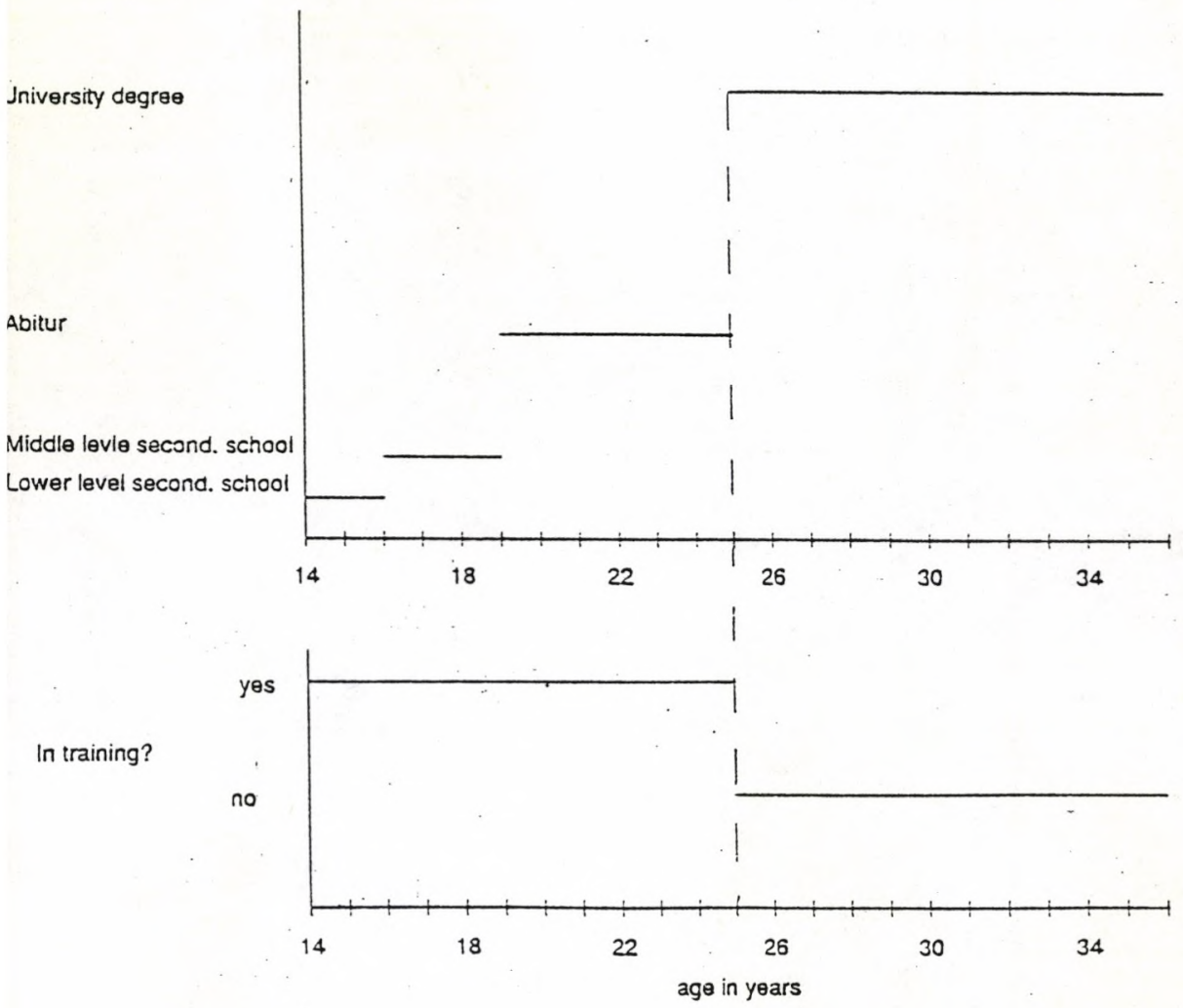



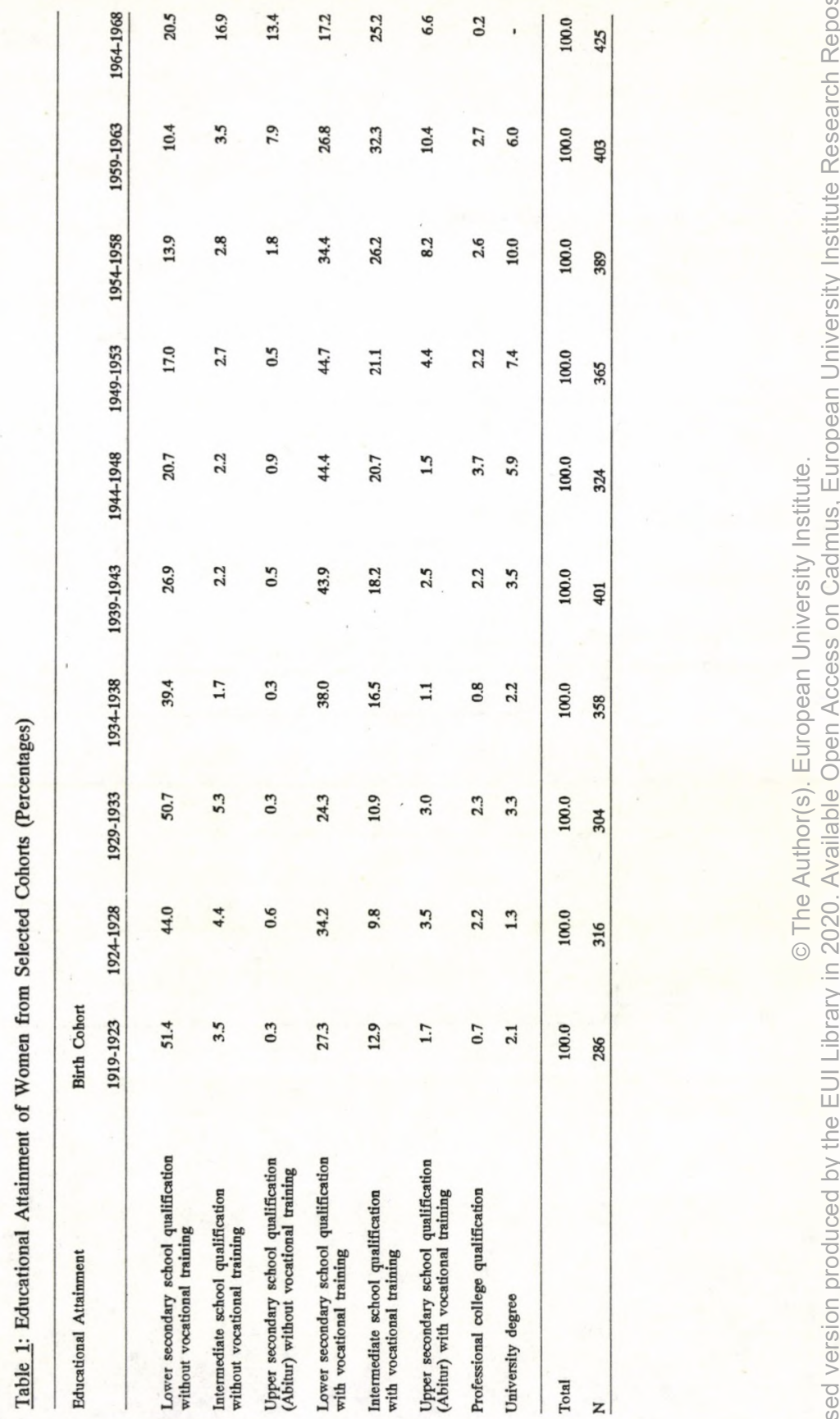

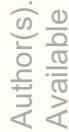
(2) 으 (2) 조 
Table 2: Changes in the Timing of Entry into Marriage, as Measured by Proportions Unmarried at Specific Ages (Percentages)

Birth Cohort

Proportion of unmarried women at age

\begin{tabular}{rrrrrrrrr}
20 & 24 & 28 & 32 & 36 & 40 & 44 & 48 & \\
\hline $1964-68$ & 89 & - & - & - & - & - & - & - \\
$1959-63$ & 78 & 40 & - & - & - & - & - & - \\
$1954-58$ & 73 & 32 & 19 & - & - & - & - & - \\
$1949-53$ & 65 & 24 & 11 & 7 & - & - & - & - \\
$1944-48$ & 65 & 15 & 7 & 4 & 3 & - & - & - \\
$1939-43$ & 80 & 21 & 8 & 5 & 3 & 3 & - & - \\
$1934-38$ & 76 & 23 & 9 & 6 & 5 & 5 & 4 & - \\
$1929-33$ & 86 & 32 & 13 & 7 & 6 & 5 & 5 & 4 \\
$1924-28$ & 90 & 40 & 16 & 11 & 8 & 6 & 5 & 5 \\
$1919-23$ & 90 & 46 & 20 & 13 & 10 & 9 & 7 & 7 \\
\hline
\end{tabular}


Table 3: Changes in the Timing of Entry into Motherhood as Measured by Proportions Childless at Specific Ages (Percentages)

Birth Cohort

Proportion of childless women at age

\begin{tabular}{rrrrrrrrr}
20 & 24 & 28 & 32 & 36 & 40 & 44 & 48 & \\
\hline $1964-68$ & 92 & - & - & - & - & - & - & - \\
$1959-63$ & 90 & 57 & - & - & - & - & - & - \\
$1954-58$ & 84 & 55 & 30 & - & - & - & - & - \\
$1949-53$ & 78 & 47 & 21 & 15 & - & - & - & - \\
$1944-48$ & 77 & 32 & 16 & 11 & 9 & - & - & - \\
$1939-43$ & 87 & 41 & 18 & 13 & 10 & 10 & - & - \\
$1934-38$ & 83 & 45 & 18 & 13 & 11 & 11 & 11 & - \\
$1929-33$ & 92 & 54 & 28 & 19 & 16 & 16 & 16 & 16 \\
$1924-28$ & 87 & 56 & 26 & 19 & 15 & 14 & 14 & 14 \\
$1919-23$ & 91 & 57 & 30 & 19 & 15 & 15 & 15 & 15 \\
\hline
\end{tabular}




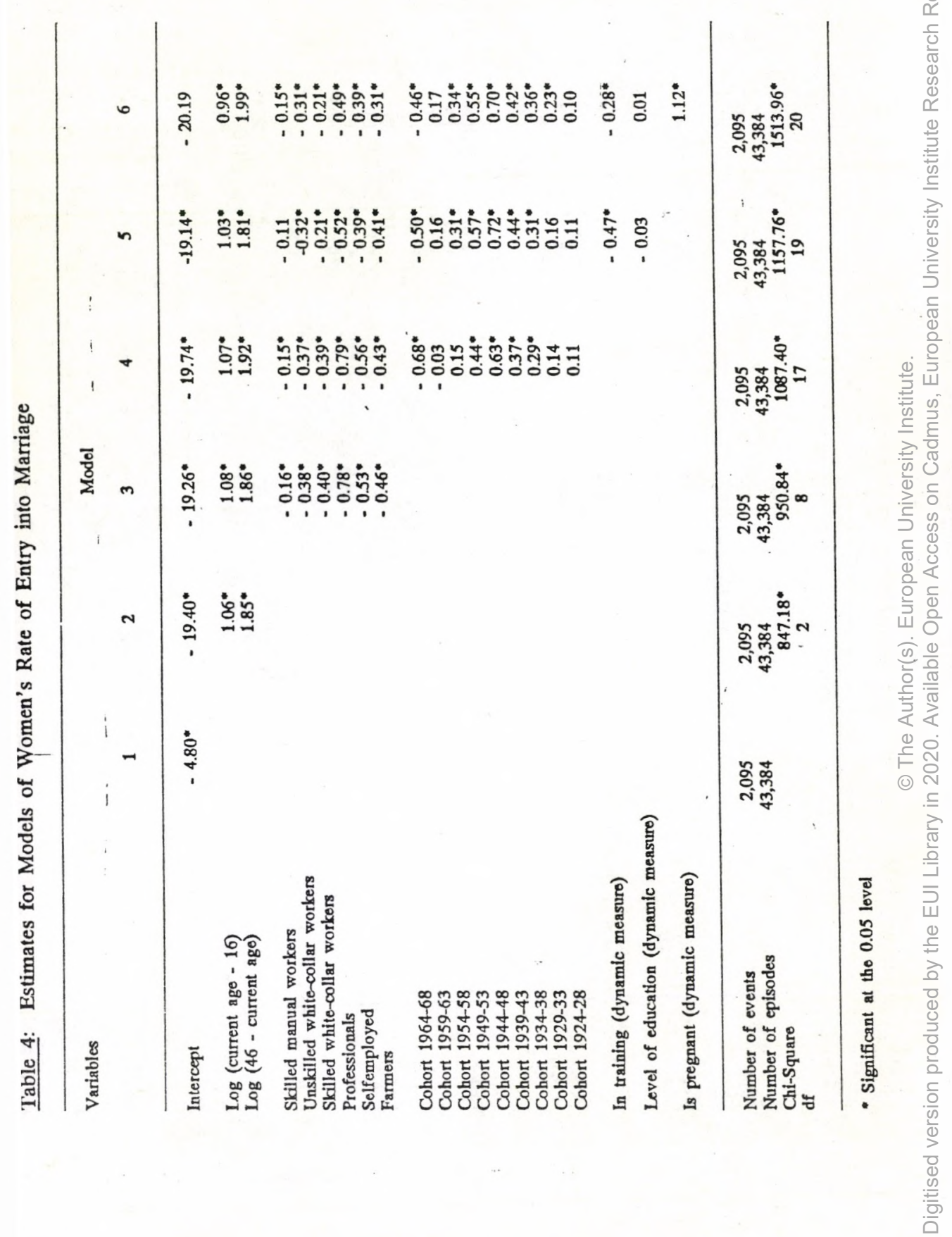




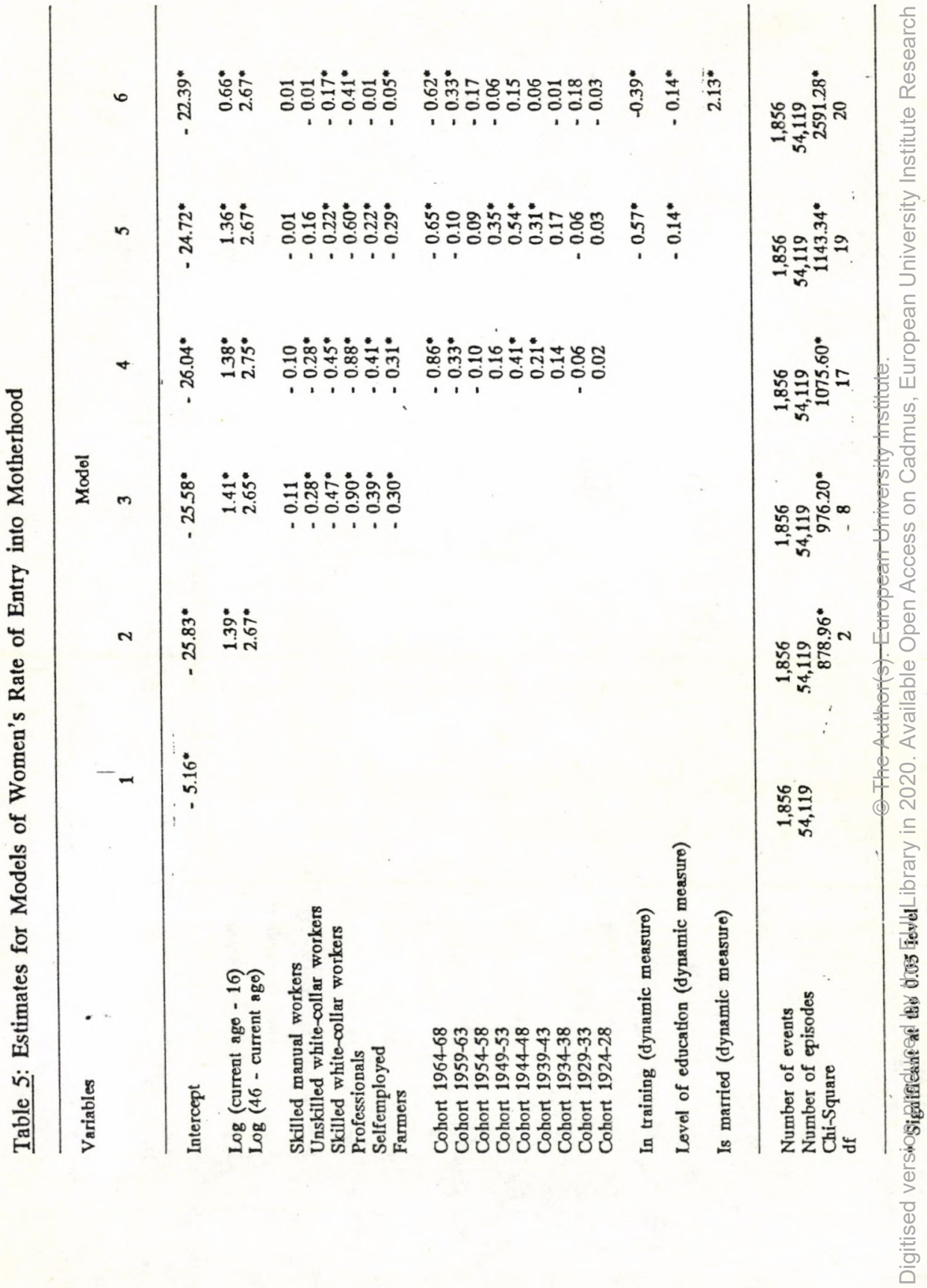




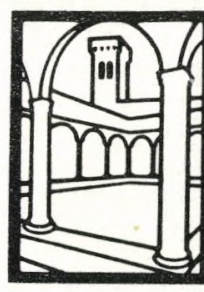

EUI WORKING PAPERS

EUI Working Papers are published and distributed by the European University Institute, Florence

Copies can be obtained free of charge - depending on the availability of stocks - from:

The Publications Officer

European University Institute

Badia Fiesolana

I-50016 San Domenico di Fiesole (FI)

Italy

Please use order form overleaf 


\section{Publications of the European University Institute}

To The Publications Officer

European University Institute

Badia Fiesolana

I-50016 San Domenico di Fiesole (FI)

Italy

From

Name

Address

$\square$ Please send me a complete list of EUI Working Papers $\square$ Please send me a complete list of EUI book publications $\square$ Please send me the EUI brochure Academic Year 1990/91

Please send me the following EUI Working Paper(s):

No, Author

Title:

No, Author

Title:

No, Author

Title:

No, Author

Title:

Date

Signature 
$89 / 412$

Gianna GIANNELLI/

Gøsta ESPING-ANDERSEN

Labor Costs and Employment in

the Service Economy

\section{$89 / 413$}

Francisco S. TORRES

Portugal, the EMS and 1992:

Stabilization and Liberalization

\section{$89 / 414$}

Gøsta ESPING-ANDERSEN/

Harald SONNBERGER

The Demographics of Age in

Labor Market Management

\section{$89 / 415$}

Fritz von NORDHEIM NIELSEN

The Scandinavian Model:

Reformist Road to Socialism or

Dead End Street?

\section{$89 / 416$}

\section{Joerg MAYER}

Reserve Switches and Exchange-

Rate Variability: The Presumed

Inherent Instability of the Multiple

Reserve-Currency System

\section{$89 / 417$}

José P. ESPERANÇA/Neil KAY

Foreign Direct Investment and Competition in the Advertising

Sector: The Italian Case

\section{$89 / 418$}

Luigi BRIGHI/Mario FORNI

Aggregation Across Agents in

Demand Systems

\section{$89 / 419$}

H. U. JESSURUN d'OLIVEIRA

Nationality and Apartheid:
Some Reflections on the Use of

Nationality Law as a Weapon

against Violation of Fundamental

Rights

\section{$89 / 420$}

Corrado BENASSI

A Competitive Model of Credit Intermediation

\section{$89 / 421$}

Ester STEVERS

Telecommunications Regulation in the European Community: The Commission of the European Communities as Regulatory Actor

$89 / 422$

Marcus MILLER/Mark SALMON When does Coordination pay?

\section{$89 / 423$}

Marcus MILLER/Mark

SALMON/

Alan SUTHERLAND

Time Consistency, Discounting and the Returns to Cooperation

$89 / 424$

Frank CRITCHLEY/Paul

MARRIOTT/Mark SALMON

On the Differential Geometry of the Wald Test with Nonlinear

Restrictions

\section{$89 / 425$}

Peter J. HAMMOND

On the Impossibility of Perfect Capital Markets

\section{$89 / 426$}

Peter J. HAMMOND

Perfected Option Markets in

Economies with Adverse Selection 
$89 / 427$

Peter J. HAMMOND

Irreducibility, Resource

Relatedness, and Survival with

Individual Non-Convexities

$89 / 428$

Joanna GOYDER

"Business Format" Franchising and EEC Competition Law 


\section{EUI Working Papers as from 1990}

As from January 1990, the EUI Working Papers Series is divided into six sub-series, each series will be numbered individually (e.g. EUI Working Paper LAW No 90/1).

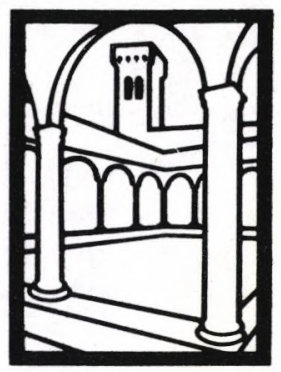

July 1990 


\section{Working Papers in Law}

LAW No. 90/1

David NELKEN

The Truth about Law's Truth
LAW No. 90/2

Antonio CASSESE/Andrew CLAPHAM/Joseph H.H. WEILER 1992 - What are our Rights? Agenda for a Human Rights Action Plan

LAW No. 90/3

Sophie PAPAEFTHYMIOU Constructivist Epistemology of Law

\section{Working Papers in European Cultural Studies}

ECS No. 90/1

Léonce BEKEMANS

European Integration and

Cultural

Policies. Analysis of a Dialectic

Polarity
ECS No. 90/2

Christine FAURE

Intellectuels et citoyenneté

en France, de la révolution

au second empire (1789-1870)

\section{Working Papers of the European Policy Unit}

EPU No. 90/1

Renaud DEHOUSSE /Joseph H.H.

WEILER

EPC and the Single Act:

From Soft Law to Hard Law?

EPU No. 90/2

Richard N. MOTT

Federal-State Relations in

U.S. Environmental Law:

Implications for the European

Community
EPU No. 90/3

Christian JOERGES

Product Safety Law, Internal

Market Policy and the Proposal

for a Directive on General

Product Safety

EPU No. 90/4

Martin WESTLAKE

The Origin and Development of the Question Time Procedure in the European Parliament 


\section{Working Papers in Economics}

ECO No. 90/1

Tamer BAŞAR/Mark SALMON

Credibility and the Value of

Information Transmission in a

Model of Monetary Policy and

Inflation

ECO No. 90/2

Horst UNGERER

The EMS - The First Ten Years

Policies - Developments -

Evolution

ECO No. 90/3

Peter J. HAMMOND

Interpersonal Comparisons of Utility: Why and how they are and should be made

ECO No. 90/4

Peter J. HAMMOND

A Revelation Principle for

(Boundedly) Bayesian

Rationalizable Strategies

ECO No. 90/5

Peter J. HAMMOND

Independence of Irrelevant

Interpersonal Comparisons

ECO No. 90/6

Hal R. VARIAN

A Solution to the Problem of

Externalities and Public Goods

when Agents are Well-Informed
ECO No. 90/7

Hal R. VARIAN

Sequential Provision of Public

Goods

ECO No. 90/8

T. BRIANZA/L. PHLIPS/J.-F. RICHARD

Futures Markets, Speculation and Monopoly Pricing

ECO No. 90/9

Anthony B. ATKINSON/John

MICKLEWRIGHT

Unemployment Compensation and Labour Market Transitions:

A Critical Review

ECO No. 90/10

Peter J. HAMMOND

The Role of Information in

Economics

ECO No. 90/11

Nicos M. CHRISTODOULAKIS Debt Dynamics in a Small Open Economy

ECO No. 90/12

Stephen C. SMITH

On the Economic Rationale for Codetermination

ECO No. 90/13

Elettra AGLIARDI

Learning by Doing and

Market Structures 


\section{Working Papers in History}

HEC No. 90/1

Elisabeth ELGAN/Jan

GRÖNDAHL

Single Mothers in Early

Twentieth Century Sweden:Two

Studies
HEC No. 90/2

Jean-Pierre CAVAILLE

Un théatre de la science et de la mort à l'époque baroque:

l'amphithéatre d'anatomie de

Leiden

\section{Working Papers in Political and Social Sciences}

SPS No. 90/1

Reiner GRUNDMANN/Christos

MANTZIARIS

Habermas, Rawls, and the

Paradox of Impartiality

SPS No. 90/2

Hans-Peter BLOSSFELD/Ursula

JAENICHEN

Educational Expansion and

Changes in Women's Entry into

Marriage and Motherhood in the

Federal Republic of Germany 
$\therefore$

D

3

त्र

$\frac{6}{2}$

5

당

(1)

은 $\frac{1}{1}$

ய

(1) $\frac{1}{0}$

든을

$\frac{1}{5} \frac{1}{4}$

है?

() 